\title{
Inhibition of growth of OV-1063 human epithelial ovarian cancers and c-jun and c-fos oncogene expression by bombesin antagonists
}

\author{
I Chatzistamou ${ }^{1,2}$, AV Schally ${ }^{1,2}$, B Sun ${ }^{1,2}$, P Armatis ${ }^{1}$ and K Szepeshazi ${ }^{1,2}$ \\ ${ }^{1}$ Endocrine, Polypeptide and Cancer Institute, Veterans Affairs Medical Center, and Section of Experimental Medicine; ${ }^{2}$ Department of Medicine, \\ Tulane University School of Medicine, New Orleans, LA 70112, USA
}

\begin{abstract}
Summary Receptors for bombesin are present on human ovarian cancers and bombesin-like peptides could function as growth factors in this carcinoma. Therefore, we investigated the effects of bombesin/gastrin-releasing peptide (GRP) antagonists RC-3940-II and RC-3095 on the growth of human ovarian carcinoma cell line OV-1063, xenografted into nude mice. Treatment with RC-3940-II at doses of $10 \mu \mathrm{g}$ and $20 \mu \mathrm{g}$ per day s.c. decreased tumour volume by $60.9 \%(P<0.05)$ and $73.5 \%(P<0.05)$ respectively, after 25 days, compared to controls. RC3095 at a dose of $20 \mu \mathrm{g}$ per day reduced the volume of OV-1063 tumours by $47.7 \%(P=0.15)$. In comparison, luteinizing hormone-releasing hormone (LH-RH) antagonist Cetrorelix at a dose of $100 \mu \mathrm{g}$ per day caused a $64.2 \%$ inhibition $(P<0.05)$. RT-PCR analysis showed that OV1063 tumours expressed mRNA for bombesin receptor subtypes BRS-1, BRS-2, and BRS-3. In OV-1063 cells cultured in vitro, GRP(14-27) induced the expression of mRNA for c-jun and c-fos oncogenes in a time-dependent manner. Antagonist RC-3940-II inhibited the stimulatory effect of GRP(14-27) on c-jun and c-fos in vitro. In vivo, the levels of c-jun and c-fos mRNA in OV-1063 tumours were decreased by $43 \%$ $(P<0.05)$ and $45 \%(P=0.05)$ respectively, after treatment with RC-3940-II at $20 \mu \mathrm{g}$ per day. Exposure of OV-1063, UCl-107 and ES-2 ovarian carcinoma cells to RC-3940-II at $1 \mu \mathrm{M}$ concentration for $24 \mathrm{~h}$ in vitro, extended the latency period for the development of palpable tumours in nude mice. Our results indicate that antagonists of bombesin/GRP inhibit the growth of OV-1063 ovarian cancers by mechanisms that probably involve the downregulation of c-jun and c-fos proto-oncogenes. (C) 2000 Cancer Research Campaign
\end{abstract}

Keywords: cancer therapy; bombesin/GRP antagonists; LH-RH antagonist; ovarian tumours; c-jun; c-fos

Ovarian epithelial carcinoma is the leading cause of death from gynaecological cancers among women in the western world. It is estimated that in 1999 approximately 25000 women in the USA will have been diagnosed with ovarian cancer and about 14000 deaths will have occurred due to this malignancy (Landis et al, 1999). Over the period 1990-1994 nearly 20000 deaths from ovarian cancer were recorded in the UK (Levi et al, 1999). Most patients with advanced epithelial ovarian cancer are presently treated with cytoreductive surgery followed by combination chemotherapy. However, the long-term outcome of such treatment is disappointing and new therapeutic strategies must be explored.

Bombesin-like peptides, such as the gastrin-releasing peptide (GRP), were initially reported as autocrine growth factors in the development and progression of some human small cell lung carcinomas (Cuttitta et al, 1985; Carney et al, 1987; Moody and Cuttitta, 1993; Siegfried et al, 1994), but recent studies also suggest an involvement of bombesin and GRP in the pathogenesis of pancreatic, prostatic, breast and other cancers, such as malignant glioblastomas (Bologna et al, 1989; Yano et al, 1992; Wang et al, 1996; Schally and Comaru-Schally, 1997; Kiaris et al, 1999; Markwalder and Reubi, 1999). Specific receptors for bombesin/GRP have been shown in various human cancers, including prostatic and mammary, in human breast, prostatic and

Received 29 November 1999

Revised 17 May 2000

Accepted 23 May 2000

Correspondence to: AV Schally pancreatic cancer lines, and in mouse mammary cancers (Szepeshazi et al, 1992; 1997; Halmos et al, 1995; Wang et al, 1996; Schally and Comaru-Schally, 1997; Markwalder and Reubi, 1999; Sun et al, 1999). Recently, the expression of receptors for bombesin-like peptides was demonstrated in human ovarian cancer specimens and ovarian cancer cell lines SW-626, OV-1063 and UCI-107 (Schally and Comaru-Schally, 1997; Kim et al, 1998; Sun et al, 1999). Until now, three subtypes of bombesin/GRP receptors have been characterized in humans: bombesin receptor subtype-1 (GRPR/BRS-1) which binds GRP with high affinity; NMBR/BRS-2, which is preferentially activated by neuromedin B; and BRS-3 (Spindel et al, 1993). BRS-3 is considered an orphan receptor with an unknown natural ligand. Recently, a fourth receptor subtype BRS-4 has been cloned and characterized in amphibia and its existence in mammals was also postulated (Nagalla et al, 1995). The peptides of bombesin/GRP family induce cell proliferation by mechanisms that involve activation of phosphatidylinositol, $\mathrm{Ca}^{2+}$ release, and stimulation of the expression of c-fos and c-jun mRNAs (Spindel et al, 1993; Draoui et al, 1995; Nagalla et al, 1995).

The findings that bombesin-like and gastrin-like peptides may function as autocrine/paracrine growth factors in certain tumours prompted the development of bombesin/GRP antagonists as potent antitumour agents (Radulovic et al, 1991; Cai et al, 1994; Reile et al, 1995; Schally and Comaru-Schally, 1997). Bombesin/GRP antagonists, such as RC-3095 and RC-3940-II, synthesized in our laboratory suppressed the growth of various tumours including prostatic, breast, lung, pancreatic, gastric and malignant glioblastomas (Szepeshazi et al, 1992; 1997; Qin et al, 1994a; 1994b; 
Shirahige et al, 1994; Jungwirth et al, 1997a; 1997b; Koppan et al, 1998; Miyazaki et al, 1998; Kiaris et al, 1999). RC-3095 and RC3940-II differ at N-terminus and at C-terminal. RC-3095 contains $\mathrm{N}$-terminal D-Tpi and C-terminal Leu, and RC-3940-II has Hca at $\mathrm{N}$-terminus and Tac at C-terminus (Hca is desaminophenylalanine; Tac is thiazolidine-4-carboxylic acid; Tpi is 2,3,4,9-tetrahydro1H-pyrido[3,4-b]indol-3-carboxylic acid). Due to their structural differences, RC-3940-II has a more restricted conformation than RC-3095 resulting in about 200 times higher binding affinity to GRP receptor than RC-3095, as demonstrated by the displacement

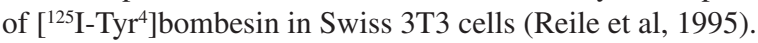

The receptors for luteinizing hormone-releasing hormone (LHRH) are also expressed by ovarian cancers (Yano et al, 1994; Chegini et al, 1996; Emons et al, 1998). Our group has previously demonstrated that chronic treatment with the LH-RH antagonist Cetrorelix, but not LH-RH agonist triptorelin, can induce a significant inhibition of growth of OV-1063 human epithelial ovarian cancer xenografted into nude mice (Yano et al, 1994). Because both LH-RH analogues cause a comparable suppression of the pituitary-gonadal axis, it was suggested that the antitumour action of Cetrorelix was exerted in part directly on LH-RH receptors in tumours (Yano et al, 1994).

In the present study we evaluated the anti-tumour effects of two bombesin/GRP antagonists, RC-3095 and RC-3940-II on the growth of human epithelial ovarian cancer cell line OV-1063, xenografted into nude mice. The results were compared to those obtained with the LH-RH antagonist Cetrorelix. In an attempt to elucidate the mechanism of action of bombesin/GRP antagonists, we investigated the effect of GRP on the expression of c-jun and c-fos mRNAs in OV-1063 cells cultured in vitro. The outcome of treatment with RC-3940-II on the mRNA levels of c-jun and c-fos was also evaluated in OV-1063 tumours xenografted into nude mice.

\section{MATERIALS AND METHODS}

\section{Peptides}

Bombesin antagonist D-Tpi ${ }^{6}, \quad \mathrm{Leu}^{13} \psi\left[\mathrm{CH}_{2} \mathrm{NH}\right] \mathrm{Leu}^{14} \mathrm{BN}(6-14)$ (RC-3095), originally synthesized in our laboratory by solid-phase methods (Radulovic et al, 1991), was manufactured by ASTA Medica (Frankfurt am Main, Germany) in the form of acetate salt, D22213. The novel BN antagonist $\mathrm{Hca}^{6}, \mathrm{Leu}^{13} \psi\left[\mathrm{CH}_{2} \mathrm{~N}\right] \mathrm{Tac}^{14}-\mathrm{BN}$ (6-14) (RC-3940-II) was synthesized by solid-phase methods and purified in our laboratory (Cai et al, 1994; Reile et al, 1995). Hca is desaminophenylalanine, Tac is thiazolidine-4-carboxylic acid, and Tpi is 2,3,4,9-tetrahydro-LH-pyrido[3,4-b]indol-3-carboxylic acid. Cetrorelix (SB-75), [Ac-D-Nal(2) ${ }^{1}, \mathrm{D}-\mathrm{Phe}(4 \mathrm{Cl})^{2}, \mathrm{D}-\mathrm{Pal}(3)^{3}$, D-Cit $\left.{ }^{6}, \mathrm{D}-\mathrm{Ala}^{10}\right] \mathrm{LHRH}$, originally synthesized in this laboratory (Bajusz et al, 1988), was obtained from ASTA Medica.

RC-3095 and RC-3940-II were dissolved in dimethyl sulphoxide (DMSO) and diluted with $0.9 \%$ saline. The final concentration of DMSO was $0.1 \%$. Cetrorelix was dissolved in distilled water containing $5 \%$ mannitol.

\section{Cell lines and cell proliferation assays}

Human ovarian cancer cell line OV-1063, and ES-2 were obtained from American Type Culture Collection (Rockville, MD, USA).
UCI-107 human ovarian carcinoma cell line was kindly provided by Dr A Manetta (University of California, Irvine, CA, USA). OV-1063 and UCI-107 cells were maintained in Roswell Park Memorial Institute 1640 (RPMI-1640) medium, and ES-2 cells in McCoy 5A medium, all supplemented with $10 \%$ foetal bovine serum (FBS), vitamins, antibiotics, and antimycotics as described previously (Horowitz et al, 1985). Cells were cultured in T-75 Flasks (Corning Costar Corp., Cambridge, MA, USA) in a humidified atmosphere of $5 \% \mathrm{CO}_{2}$ and $95 \%$ air at $37^{\circ} \mathrm{C}$ and passed every 4-6 days using 0.25\% trypsin-EDTA (Yano et al, 1994). For the evaluation of the c-jun and c-fos mRNA levels, cells were cultured for $18 \mathrm{~h}$ as described previously, except that the tissue culture medium contained $2 \%$ FBS during the exposure to GRP or RC$3940-$ II at $10^{-7} \mathrm{M}$ for $1-5 \mathrm{~h}$. The effect of RC-3940-II on the rate of cell proliferation was evaluated by the crystal violet method as described previously (Bernhardt et al, 1992). The results were calculated as $\% \mathrm{~T} / \mathrm{C}$, where $\mathrm{T}=$ optical density of treated cultures and $\mathrm{C}=$ optical density of untreated cultures.

\section{Studies on tumorigenicity}

OV-1063, ES-2 and UCI-107 cells were exposed in vitro to $10^{-6} \mathrm{M}$ RC-3940-II for $24 \mathrm{~h}$. Subsequently, $2 \times 10^{5}$ cells per animal were injected s.c. into the right flanks of nude mice and the period during which palpable tumours, measuring about $15 \mathrm{~mm}^{3}$, developed was recorded. Animals were observed daily until tumours were developed in all experimental animals.

\section{Histological methods}

Histological analyses were performed in OV-1063 tumours xenografted into nude mice. Mitotic and apoptotic cells were counted in tumour slides stained with haematoxylin-eosin as described earlier (Szepeshazi et al, 1992) and their number per 1000 cells were accepted as the mitotic and apoptotic indices. For the demonstration of the nucleolar organizer regions (NOR) in tumour cell nuclei, the AgNOR method was used as described previously (Szepeshazi et al, 1992).

Proliferating cell nuclear antigen (PCNA) was detected by immunohistochemistry as follows. Sections from paraffinembedded tumour samples were placed on silanated slides, dewaxed and rehydrated. Slides were immersed in distilled water and heated in a domestic microwave oven for $2 \times 5 \mathrm{~min}$. All incubations were performed at room temperature as follows: blocking solution $3 \%$ bovine serum albumin for $30 \mathrm{~min}$, monoclonal antiPCNA (Calbiochem, La Jolla, CA, USA), at 1:500 for $60 \mathrm{~min}$, biotinylated anti-mouse IgG (Sigma, St. Louis, MO, USA), 1:400 for $60 \mathrm{~min}$ and Extravidine-peroxidase (Sigma), 1:100 for $60 \mathrm{~min}$. The product was visualized by 3,3'-diaminobenzidine (Sigma Fast DAB). Sections were evaluated at areas showing the highest positivity. The positive and negative nuclei were counted in three microscopic areas each containing about 330 cells, and the percentage ratio of positive cells to total cells was calculated.

\section{Animals}

Five to 6-week-old female athymic Ncr nu/nu nude mice were obtained from Frederick Cancer Research facility of the National Cancer Institute (Frederick, MD, USA). The mice were housed in sterile cages under laminar flow hoods in a temperature-controlled 
room with a 12-h dark schedule and were fed autoclaved chow and water ad libitum. Their care was in accord with institutional ethical guidelines for the welfare of animals.

\section{Experimental protocol}

Xenografts of OV-1063 cells were initiated by s.c. injection of $10^{7}$ cells into the right flank of three nude mice. Tumours resulting after 4 weeks were aseptically dissected and mechanically minced: $1 \mathrm{~mm}^{3}$ tumour pieces were transplanted subcutaneously by trocar needle into the right flank of the mice. The tumour take rate was nearly $90 \%$. Two weeks after tumour transplantation and while the tumours measured approximately $30-40 \mathrm{~mm}^{3}$, the mice were divided into five experimental groups of seven animals each and received the following treatment as s.c. injections: group 1 (control), vehicle solution; group 2, RC-3095 at a dose of $20 \mu \mathrm{g}$ per day; group 3, RC-3940-II at a dose of $20 \mu \mathrm{g}$ per day; group 4, RC-3940II at a dose of $10 \mu \mathrm{g}$ per day; group 5, Cetrorelix (SB-75) at a dose of $100 \mu \mathrm{g}$ per day. The treatment was continued for 25 days. The dose of the analogues was determined on the basis of previous studies using different tumour models. Tumours were measured once a week with a microcaliper and the volume was calculated by the formula of length $\times$ width $\times$ height $\times 0.5236$ (Tomayko and Reynolds, 1989). At the end of the experiment, mice were anaestaetized with methoxyflurane (Metofane; Pitman-Moore, Mundelein, IL, USA) and sacrificed by decapitation. Trunk blood was collected and centrifuged at $1000 \mathrm{~g}$ for $30 \mathrm{~min}$ at $4^{\circ} \mathrm{C}$ and serum was stored at $-20^{\circ} \mathrm{C}$ until assayed. Body weights were recorded and various organs were removed and weighed. Tumours were carefully removed, cleaned and weighed. Tumour burden at the end of the experiment was calculated as tumour weight $(\mathrm{mg})$ per body weight (g). Tumour pieces were stored at $-80^{\circ} \mathrm{C}$ for molecular biology analysis. All experiments were approved by the institutional ACUC and the procedures were essentially in accordance with UKCCCR guidelines (1998) for the welfare of animals in experimental neoplasia.

\section{RNA extraction}

Total RNA was extracted from frozen tissue samples by using RNAsol B (TEL-TEST Inc., Friendswood, TX, USA) according to the manufacturer's instructions. The RNA pellets were suspended in $50 \mu \mathrm{l}$ of $10 \mathrm{mM}$ Tris, $1 \mathrm{mM}$ EDTA buffer ( $\mathrm{pH}$ 8.0) and quantified spectrophotometrically at $260 \mathrm{~nm}$.

\section{Reverse transcription-PCR (RT-PCR)}

One microgram of total RNA was used in a test tube containing $10 \mathrm{mM}$ Tris-HCI (pH 8.3), $50 \mathrm{mM} \mathrm{KCI}, 5 \mathrm{mM} \mathrm{MgCI}, 1 \mathrm{mM}$ of each deoxynucleoside triphosphate, $1 \mathrm{U}$ Rnase inhibitor, and $2.5 \mu \mathrm{M}$ random hexamer primers in a final volume of $19 \mu \mathrm{l}$ of Rnase-free deionized distilled water. The mixture was heated for $10 \mathrm{~min}$ at $65^{\circ} \mathrm{C}$, quenched on ice, then $2.5 \mathrm{U}$ of Moloney murine leukaemia virus reverse transcriptase (Perkin-Elmer Corp., Norwalk, CT, USA) in $1 \mu \mathrm{l}$ was added, for a total reaction volume of $20 \mu \mathrm{l}$. The mixture was incubated at room temperature for $10 \mathrm{~min}$ and then at $42^{\circ} \mathrm{C}$ for $1 \mathrm{~h}$. The reaction was ended by heating at $95^{\circ} \mathrm{C}$ for $5 \mathrm{~min}$ and quenching on ice. The PCR amplification of the cDNAs for human glyceraldehyde-3-phosphate dehydrogenase (hGAPDH), GRP, c-fos, c-jun, GRPR, BRS-3 and NMBR, was performed as follows. One microlitre of the cDNA was amplified in a $50 \mu \mathrm{l} \mathrm{solu-}$ tion containing $10 \mathrm{mM}$ Tris. $\mathrm{HCl}(\mathrm{pH} 8.3), 50 \mathrm{mM} \mathrm{KCl}, 1.7 \mathrm{mM}$ $\mathrm{MgCl}_{2}, 200 \mu \mathrm{M}$ of each dNTP, 2.5 Units Taq polymerase and $0.4 \mu \mathrm{M}$ of each primer. The nucleotide sequence and the expected PCR products for the oligonucleotide primers used are shown in Table 1 (Kiaris et al, 1999; Sun and Schally, 1999). PCR consisted of one cycle at $95^{\circ} \mathrm{C}$ for $3 \mathrm{~min}, 58^{\circ} \mathrm{C}$ for $1 \mathrm{~min}$, and $72^{\circ} \mathrm{C}$ for $1 \mathrm{~min}$ and subsequently 26 (hGAPDH), 30 (GRP), 29 (c-jun), 32 (c-fos), cycles of $95^{\circ} \mathrm{C}$ for $35 \mathrm{~s}, 58^{\circ} \mathrm{C}$ for $40 \mathrm{~s}$, and $72^{\circ} \mathrm{C}$ for $40 \mathrm{~s}$ by using a Stratagene Robocycler 40 System. For the multiplex PCRs, the cDNA for each target gene was amplified simultaneously with the cDNA for hGAPDH, after supplementation of the primers for hGAPDH at the appropriate cycle at $95^{\circ} \mathrm{C}$. For the detection of GRP, after the first round of PCR, $1 \mu \mathrm{l}$ of the PCR product was subjected to a second round of PCR consisting of 28 cycles. All other parameters for the second round of PCR amplification were similar to those described above for the first round of PCR amplification. PCR amplification for GRPR, NMBR, and BRS-3 was performed in Perkin Elmer DNA thermal cycler model 2400. Samples were denatured at $94^{\circ} \mathrm{C}$ for $5 \mathrm{~min}$ and then subjected to 40 cycles comprised of $94^{\circ} \mathrm{C}$ for $1 \mathrm{~min}, 52^{\circ} \mathrm{C}$ for $1 \mathrm{~min}$ and $72^{\circ} \mathrm{C}$ for 1 min for GRPR and BRS-3 ( $1 \mu$ products of the first PCR amplification were subjected to additional 30 cycles by using nested primers); 40 cycles of $94^{\circ} \mathrm{C}$ for $30 \mathrm{~s}, 62^{\circ} \mathrm{C}$ for $30 \mathrm{~s}$ and $72^{\circ} \mathrm{C}$ for 30 $\mathrm{s}$ for NMBR, 25 cycles of $94^{\circ} \mathrm{C}$ for $30 \mathrm{~s}, 60^{\circ} \mathrm{C}$ for $30 \mathrm{~s}$ and $72^{\circ} \mathrm{C}$ for $30 \mathrm{~s}$ for hGAPDH, followed by a final extension at $72^{\circ} \mathrm{C}$ for $5 \mathrm{~min}$. In all RT-PCR amplifications negative controls were included, in which $\mathrm{H}_{2} \mathrm{O}$ instead of RNA was used as template. Aliquots of PCRamplified product were resolved by electrophoresis on a $1.8 \%$

Table 1 Nucleotide sequence and size of the expected PCR products for oligonucleotide primers used for RT-PCR

\begin{tabular}{|c|c|c|}
\hline Gene & Sequence & PCR product (bp) \\
\hline \multirow[t]{2}{*}{ hGAPDH } & 5'-TCCTCTGACTTCAACAGCGACACC-3' & 207 \\
\hline & 5'-TCTCTCTTCСTCTTGTGCTCTTGG-3' & \\
\hline \multirow[t]{2}{*}{ GRP } & 5'-TGCAAGAATTTGCTGGGTCTC-3' & 485 \\
\hline & 5'-TGTGAATGGTAACAGCTGGGG-3' & \\
\hline \multirow[t]{2}{*}{ c-fos } & 5'-AAGGAGAATCCGAAGGGAAAGGAATAAGATGGCT-3' & 612 \\
\hline & 5'-AGACGAAGGAAGACGTGTAAGCAGTGCAGCT-3' & \\
\hline \multirow[t]{2}{*}{ c-jun } & 5'-GCATGAGGAACCGCATCGCTGCCTCCAAGT-3' & 409 \\
\hline & 5'-GCGACCAAGTCCTTCCCACTCGTGCACACT-3' & \\
\hline \multirow[t]{2}{*}{ GRPR } & 5'-ATTTGGCAGGATTGGCTGC-3' & 158 \\
\hline & 5'-TGAGGCAGATCTTCATCAG-3' & \\
\hline \multirow[t]{2}{*}{ BRS-3 } & 5'-GCTCTGTGGTTTCTAACG-3' & 375 \\
\hline & 5'-CTGCCTTGTATCTGTCAGC-3' & \\
\hline \multirow[t]{2}{*}{ NMBR } & 5'-CGGACTTCTGCTGGAAAGGA-3' & 484 \\
\hline & 5'-GACGTCTGCATGTCCATGG-3' & \\
\hline
\end{tabular}


agarose gel, stained with ethidium bromide, and visualized under ultraviolet light. For quantitation of PCR-amplified products, a scanning densitometer (model GS-700, Bio-Rad) was used, coupled with the Bio-Rad personal analysis software.

\section{Statistical analysis}

Data are expressed as mean \pm SE. Statistical analyses were performed using Duncan's new multiple range test (Steel and Torrie, 1976) and Student's two-tailed $t$-test, one-way Anova and Dunnett's test. All $P$-values are based on two-sided hypothesis testing.

\section{RESULTS}

\section{Effects of treatment with bombesin/GRP antagonists RC-3095 and RC-3940-II and LH-RH antagonist Cetrorelix on OV-1063 tumours in nude mice}

After 25 days of treatment, the volume of OV-1063 tumours in the two groups receiving the bombesin/GRP antagonist RC-3940-II, was significantly reduced to $749.1 \pm 141 \mathrm{~mm}^{3}(P<0.05)$ for the high-dose group $\left(20 \mu \mathrm{g}\right.$ per day) and to $1102.5 \pm 151 \mathrm{~mm}^{3}$ $(P<0.05)$ for the low-dose group $(10 \mu \mathrm{g}$ per day) as compared with the controls $\left(2820.4 \pm 348.6 \mathrm{~mm}^{3}\right)$, corresponding to decreases of $73.5 \%$ and $60.9 \%$ in tumour volume, respectively (Table 2, Figure 1). OV-1063 tumours in mice treated with the bombesin/GRP antagonist RC-3095 measured $1481 \pm 531.4 \mathrm{~mm}^{3}$, indicating a $47.7 \%$ decrease in tumour volume $(P=0.15)$. In the group treated with LH-RH antagonist Cetrorelix, the tumour volume was reduced to $1009.3 \pm 249.2 \mathrm{~mm}^{3}$, corresponding to a $64.2 \%(P<0.05)$ decrease. The final tumour weights were also significantly diminished by $58.8 \%$ and $45.3 \%$ in the groups treated with the high-dose $(P<0.05)$ and the low-dose of RC-3940-II $(P<0.05)$, respectively. The tumour weight reduction in the group injected with Cetrorelix was $52.4 \%(P<0.05)$ and in the group receiving $\mathrm{RC}-3095,30.9 \%$ (not significant), as compared to controls (Table 2). A significant $(P<0.01)$ decrease in the weight of ovaries was observed in the group that received Cetrorelix. No significant differences in body weights and the weights of various organs such as liver, kidneys, and heart were observed between the control and the treated animals.

\section{Effect of bombesin/GRP antagonists RC-3095 and $\mathrm{RC}-3940-$ Il on the rate of cell proliferation}

Cells cultured in vitro were exposed to bombesin/GRP antagonists at various concentrations and their proliferation was monitored. Using the crystal violet method, no significant effect was found on

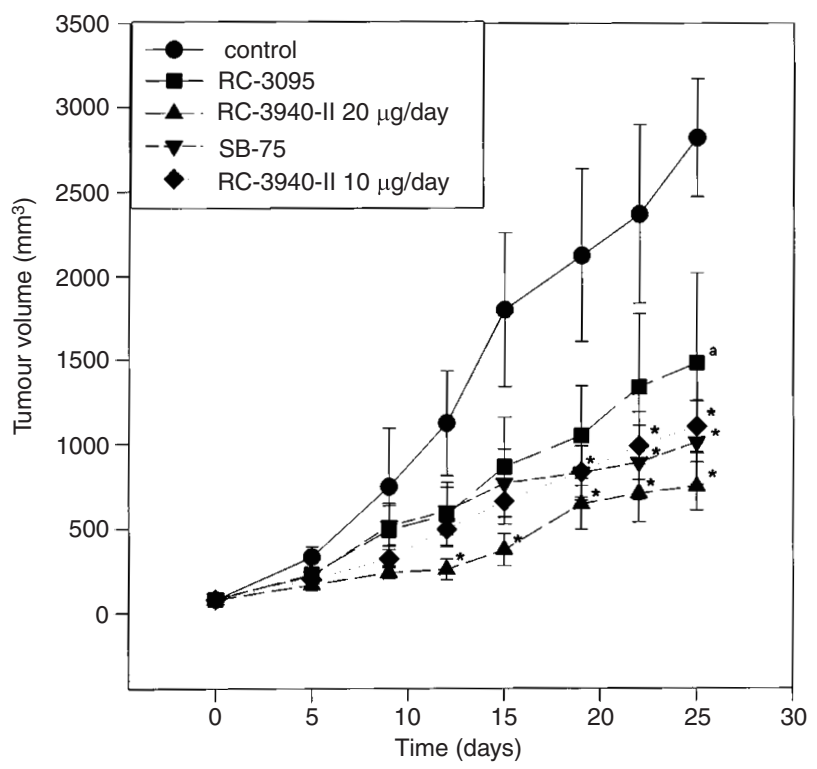

Figure 1 Tumour volumes in athymic female nude mice bearing s.c. transplanted OV-1063 human epithelial ovarian cancer cell line during treatment with bombesin/GRP antagonists RC-3940-II at doses of 10 and $20 \mu \mathrm{g}$ per animal and RC-3095 at a dose of $20 \mu \mathrm{g}$ per animal, and $\mathrm{LH}-\mathrm{RH}$ antagonist Cetrorelix at a dose of $100 \mu \mathrm{g}$ per animal administered by daily s.c. injections. Vertical bars represent SE; ${ }^{*} P<0.05$ vs control; a $P=0.15$

the proliferation rate of OV-1063, ES-2 and UCI-107 ovarian carcinoma cells after exposure to RC-3095 or RC-3940-II at $10^{-7}-10^{-5} \mathrm{M}$ (data not shown).

\section{Effect of bombesin/GRP antagonist RC-3940-II on tumorigenicity of ovarian cancer cells}

Before the injection into nude mice, OV-1063, UCI-107 and ES-2 ovarian carcinoma cells were exposed to RC-3940-II for $24 \mathrm{~h}$ at $10^{-6} \mathrm{M}$ and the number of animals bearing palpable tumours was recorded daily. As shown in Figure 2, the latency period for the development of palpable tumours was extended by the pre-treatment with RC-3940-II from $11.1 \pm 1.0$ days to $14.6 \pm 1.0$ days for OV1063 cells, from $7.5 \pm 0.9$ days to $13 \pm 0.8$ days for UCI-107 cells and from $7.9 \pm 1.5$ days to $14 \pm 1.0$ days for ES- 2 cells. These findings indicated that the latency period for the establishment of OV-1063, UCI-107 and ES-2 xenografts into nude mice was significantly extended by $32 \%(P<0.05$ vs controls $), 73 \%$ $(P<0.001$ vs controls) and $77 \%(P<0.01$ vs controls $)$, respectively.

Table 2 Effect of treatment with bombesin/GRP antagonists RC-3095 and RC-3940-II and LH-RH antagonist Cetrorelix on tumour volume and weight in nude mice bearing xenografts of OV-1063 human epithelial ovarian cancer cell line

\begin{tabular}{|c|c|c|c|c|}
\hline Treatment & $\begin{array}{l}\text { Intitial tumour } \\
\text { volume }\left(\mathrm{mm}^{3}\right)\end{array}$ & $\begin{array}{l}\text { Final tumour } \\
\text { volume }\left(\mathrm{mm}^{3}\right)\end{array}$ & $\begin{array}{c}\text { Tumour } \\
\text { weight (g) }\end{array}$ & $\begin{array}{l}\text { Tumour burden } \\
\text { (mg g-1 bw) }\end{array}$ \\
\hline Control & $79.3 \pm 17.4$ & $2820.4 \pm 348.6$ & $4.88 \pm 0.67$ & $146.0 \pm 19.0$ \\
\hline RC-3095 & $81.0 \pm 23.4$ & $1481.4 \pm 531.4$ & $3.37 \pm 0.87$ & $107.0 \pm 25.9$ \\
\hline $\begin{array}{l}\text { RC-3940-II/ } \\
20 \mathrm{gg} \mathrm{ml}^{-1}\end{array}$ & $78.3 \pm 12.8$ & $749.1 \pm 141.0^{a}$ & $2.01 \pm 0.35^{a}$ & $72.4 \pm 13.3^{a}$ \\
\hline $\begin{array}{l}\text { RC-3940-II/ } \\
\quad 10 \mu \mathrm{g} \mathrm{ml}^{-1}\end{array}$ & $81.3 \pm 11.2$ & $1102.5 \pm 151.0^{a}$ & $2.67 \pm 0.41^{a}$ & $89.9 \pm 13.7^{a}$ \\
\hline Cetrorelix & $86.5 \pm 14.5$ & $1009.3 \pm 249.2^{\mathrm{a}}$ & $2.32 \pm 0.61^{a}$ & $76.6 \pm 16.7^{\mathrm{a}}$ \\
\hline
\end{tabular}

a $P<0.05$ 

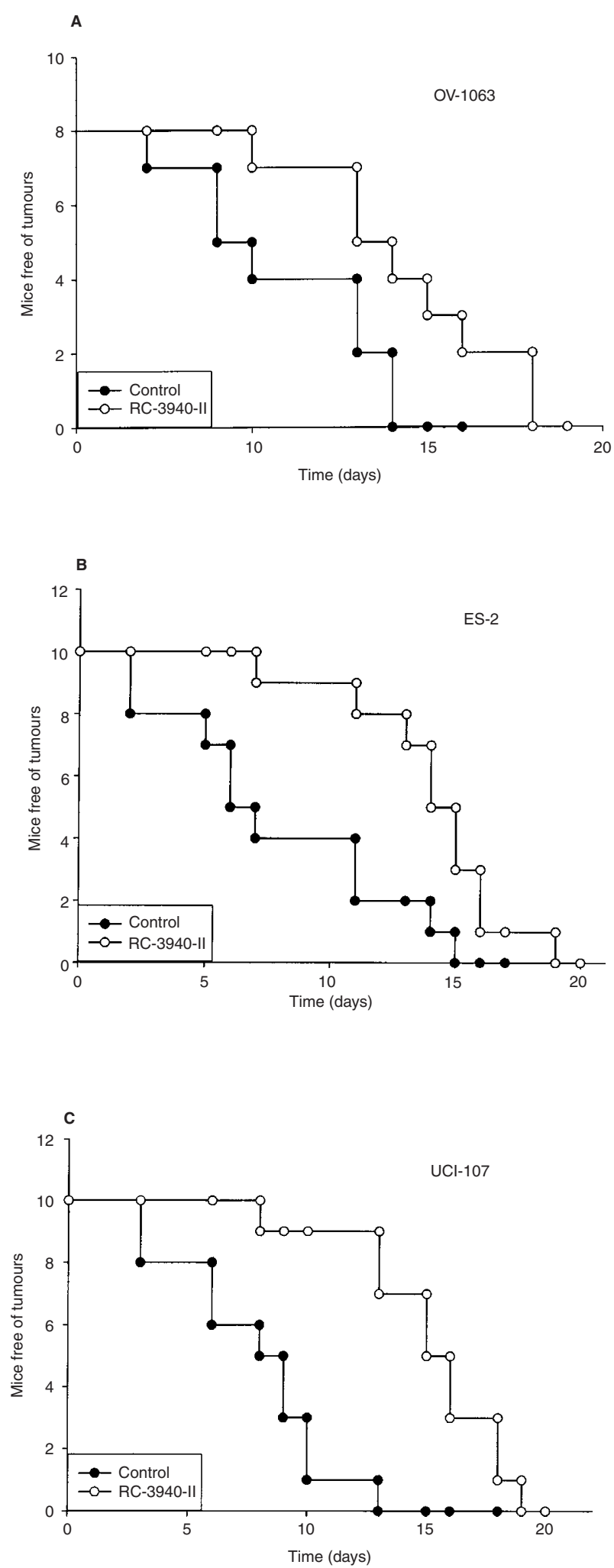

Figure 2 Effect of bombesin/GRP antagonist RC3940-II on the tumorigenicity of OV-1063 (A), ES-2 (B) and UCl-107 (C) ovarian carcinoma cells. Cells were exposed in vitro to RC-3940-II at $10^{-6} \mathrm{M}$ for $24 \mathrm{~h}$ and subsequently injected s.c. into nude mice at $2 \times 10^{5}$ cells per animal. The number of the tumour-bearing animals was recorded daily until all animals developed palpable tumours

\section{Histological findings}

The results of the histological analysis are summarized in Table 3. Bombesin/GRP antagonist RC-3940-II administered at $10 \mu \mathrm{g}$ per day or at $20 \mu \mathrm{g}$ per day decreased significantly $(P<0.05)$ the AgNOR numbers in the OV-1063 tumours as compared with the controls, while RC-3095 administered at $20 \mu \mathrm{g}$ per day did not cause any significant reduction. PCNA expression was decreased only by Cetrorelix and RC-3940-II (at doses of $20 \mu \mathrm{g}$ per day) $(P<0.05)$. Cetrorelix was also the only antagonistic analogue that increased significantly $(P<0.05)$ the apoptotic index and the ratio of apoptotic to mitotic indices in OV-1063 tumours, compared to controls. PCNA indices showed significant correlation with AgNOR counts $(r=0.556, P=0.013)$, but not with mitotic indices.

\section{Investigation of the expression of mRNA for GRP and bombesin receptor subtypes in OV-1063 human ovarian epithelial cell carcinoma}

The expression of mRNA for GRP and bombesin receptor subtypes BRS-1 (GRPR), BRS-2 (NMBR) and BRS-3 in OV-1063 tumours was evaluated by RT-PCR. As shown in Figure 3, mRNA for GRPR, NMBR and BRS-3 was detected in OV-1063 tumours, but no mRNA for the GRP ligand could be found. To confirm the absence of expression of mRNA for GRP, PCR products were subjected to a second round of PCR amplification which was again negative for the expected $485 \mathrm{bp}$ band (Figure 4).

\section{Effect of GRP and bombesin/GRP antagonist RC-3940-II on mRNA expression of c-jun and c-fos oncogenes in vitro and in vivo}

In an attempt to investigate further the mechanism of anti-tumour action of bombesin/GRP antagonists, we studied the role of GRP(14-27) on the expression of mRNA for c-jun and c-fos oncogenes, in vitro. The mRNA levels of c-jun and c-fos oncogenes were assessed by RT-PCR after exposure of OV-1063 cells cultured in vitro to $10^{-7} \mathrm{M}$ GRP(14-27) for $1 \mathrm{~h}, 3 \mathrm{~h}$ and $5 \mathrm{~h}$. As shown in Figure 5, the maximal stimulation of c-jun mRNA levels, about $436 \%$ vs basal, was observed $1 \mathrm{~h}$ after the exposure to GRP(14-27), while the greatest increase in c-fos mRNA levels, about $169 \%$ vs basal, was obtained after $5 \mathrm{~h}$ incubation with GRP(14-27). The stimulation of mRNA for c-jun and c-fos by GRP(14-27) was suppressed in the presence of $10^{-7} \mathrm{M}$ bombesin/GRP antagonist RC-3940-II. In vivo, the treatment of mice bearing OV-1063 xenografts with RC-3940-II at a dose of $20 \mu \mathrm{g}$ per day resulted in a significant decrease of $43 \%(P<0.05)$ and $45 \%(P<0.05)$ in the mRNA levels for c-jun and c-fos oncogenes respectively, while RC-3040-II at $10 \mu \mathrm{g}$ per day had no effect (Figure 6).

\section{DIscussion}

The present study shows for the first time that an antagonist of bombesin/GRP, RC-3940-II, can significantly inhibit the growth of OV-1063 human ovarian epithelial cancers xenografted into nude mice when administered at doses of $10 \mu \mathrm{g}$ and $20 \mu \mathrm{g}$ per day. The anti-tumour action of RC-3940-II is in agreement with the decrease in the expression of PCNA and AgNOR numbers in OV1063 tumours xenografted into nude mice. PCNA and AgNOR are 
Table 3 Effect of treatment with bombesin/GRP antagonists RC-3095 and RC-3940-II and LH-RH antagonist Cetrorelix on various histological parameters of OV-1063 human ovarian carcinomas xenografted into nude mice

\begin{tabular}{|c|c|c|c|c|c|}
\hline Groups & Mitotic index & $\begin{array}{c}\text { Apoptotic } \\
\text { index }\end{array}$ & $\begin{array}{c}\text { Ratio } \\
\text { apoptotic: } \\
\text { mitotic indices }\end{array}$ & $\begin{array}{l}\text { AgNORs per } \\
\text { cell }(n)\end{array}$ & $\begin{array}{c}\text { PCNA index } \\
(\%)\end{array}$ \\
\hline Control & $14.0 \pm 2.9$ & $3.4 \pm 0.4$ & $0.29 \pm 0.08$ & $6.65 \pm 0.17$ & $89.1 \pm 0.8$ \\
\hline $\begin{array}{c}\text { RC-3940-II/ } \\
20 \mu \mathrm{g}\end{array}$ & $12.3 \pm 1.3$ & $4.5 \pm 0.9$ & $0.40 \pm 0.13$ & $5.85 \pm 0.19^{a}$ & $83.1 \pm 0.7^{a}$ \\
\hline $\begin{array}{c}\text { RC-3940-II/ } \\
10 \mu \mathrm{g}\end{array}$ & $7.9 \pm 0.7$ & $5.6 \pm 0.7$ & $0.72 \pm 0.06$ & $5.93 \pm 0.18^{a}$ & $85.3 \pm 1.4$ \\
\hline RC-3095 & $14.5 \pm 0.9$ & $4.3 \pm 0.7$ & $0.30 \pm 0.06$ & $6.00 \pm 0.06$ & $86.7 \pm 1.0$ \\
\hline SB-75 & $12.5 \pm 1.7$ & $10.4 \pm 1.3^{a}$ & $0.90 \pm 0.21^{a}$ & $5.95 \pm 0.13^{a}$ & $84.8 \pm 0.7^{a}$ \\
\hline
\end{tabular}

Values are means $\pm \mathrm{SE}$. ${ }^{\mathrm{a}} P<0.05$ vs control
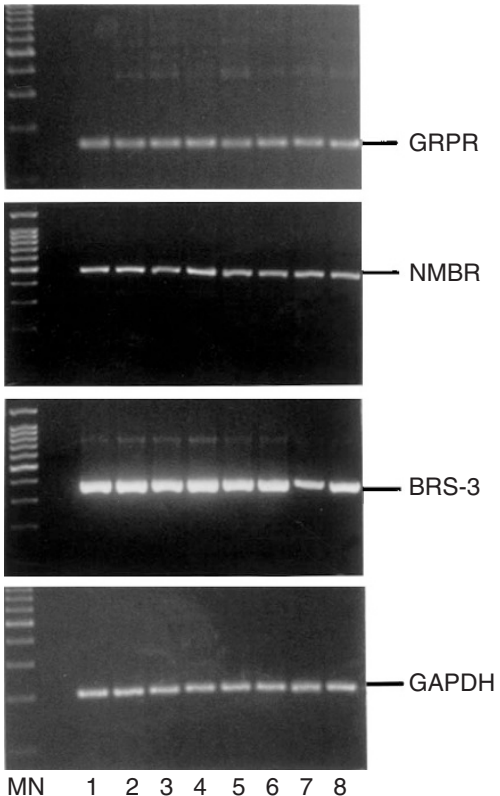

Figure 3 Expression of bombesin receptor subtypes in OV-1063 human ovarian cancers. Lanes 1, 2 = control groups; lanes 3,4 = groups treated with RC-3940-II (20 $\mu \mathrm{g}$ per day); lanes 5, 6 = groups treated with RC-3940-II $(10 \mu \mathrm{g}$ per day); lane 7,8 = groups treated with RC-3095; $\mathrm{M}=\mathrm{DNA}$ molecular marker; $\mathrm{N}=$ negative control

markers of cell proliferation and their expression is increased in highly proliferative tissues. RC-3940-II also extended significantly the latency period for the development of palpable tumours in OV-1063, ES-2 and UCI-107 human ovarian carcinoma cells. This finding was most likely due to the direct effect on tumorigenicity and not to the cytotoxicity of bombesin/GRP antagonists on these cells, because exposure of OV-1063, ES-2 and UCI-107 cells cultured in vitro to RC-3940-II had no effect on the rate of cell proliferation. Another antagonist of bombesin/GRP, RC-3095, previously developed in our laboratory, was less potent than RC3940-II in inhibiting the growth of OV-1063 tumours. The antitumour effects of bombesin/GRP antagonists RC-3095 and RC-3940-II were also compared with the effects of LH-RH antagonist Cetrorelix, which has been previously shown to inhibit the proliferation of this tumour (Yano et al, 1994). Our results showed that RC-3940-II was marginally, but not significantly, more potent than Cetrorelix in inhibiting OV-1063 tumour growth. Treatment with Cetrorelix significantly enhanced apoptosis and increased the

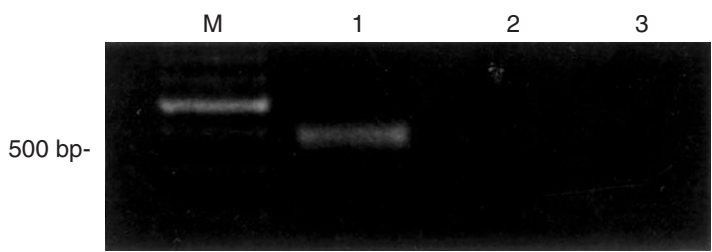

Figure 4 Expression of mRNA for GRP ligand. Lane 1 = positive contro (RNA isolated from NCl-H-69 small cell lung carcinoma); lane $2=\mathrm{RNA}$ isolated from OV-1063 human ovarian epithelial cancer cell line; lane $3=$ negative contro

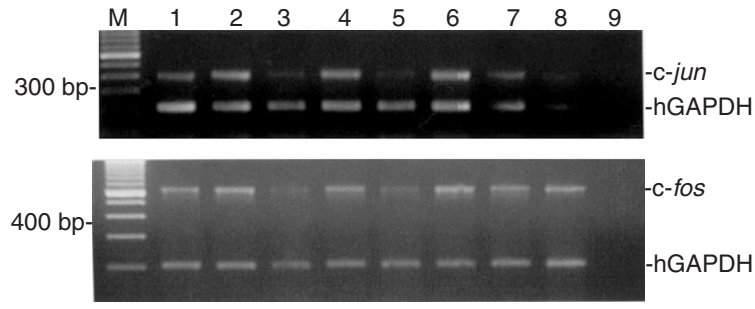

Figure 5 Expression of c-jun and c-fos mRNA in OV-1063 human ovarian epithelial cancer cell line. Total RNA was extracted from cells cultured in vitro, and c-jun and hGAPDH as well as c-fos and hGAPDH were coamplified by multiplex RT-PCR and electrophoresed on $2 \%$ agarose. Each RT-PCR reaction was repeated at least three times and similar results were obtained. Lane 1 = expression of c-jun and c-fos mRNA in cells without pretreatment; lanes 2, 4, 6 = expression of c-jun and c-fos in cells treated with $10^{-7}$ MGRP(14-27) for $1 \mathrm{~h}, 3 \mathrm{~h}$, and $5 \mathrm{~h}$; lanes 3, 5, $7=$ expression of c-jun and c-fos mRNA in cells treated with a mixture of $10^{-7} \mathrm{M} \mathrm{RC}-3940-\mathrm{II}$ and $10^{-7}$ M GRP(14-27); lane $8=$ expression of $c-j u n$ and $c$-fos in cells treated with RC-3940-II alone; lane 9 = negative control; $M=$ DNA molecular size marker

ratio of apoptotic to mitotic indices, which is in agreement with previous findings on the regulation of apoptosis by $\mathrm{LH}-\mathrm{RH}$ analogues. That only Cetrorelix, and not RC-3940-II, induced apoptosis in OV-1063 tumours, while both significantly inhibited tumour growth to similar levels, is probably due to differences in the mechanism of anti-tumour action between these antagonists. This is also supported by previous findings that co-administration of Cetrorelix and bombesin/GRP antagonists produces additive effects on inhibition of tumour growth (Yano et al 1993; Jungwirth et al $1997 a ; 1997 b ; 1998)$.

In an attempt to investigate the mechanism of action of bombesin/GRP antagonists, we tested the effect of GRP(14-27) on the expression of mRNA for c-jun and c-fos oncogenes, which are regulated by the bombesin-like peptides in small cell lung carcinomas and malignant glioblastomas (Draoui et al, 1995; Kiaris et 


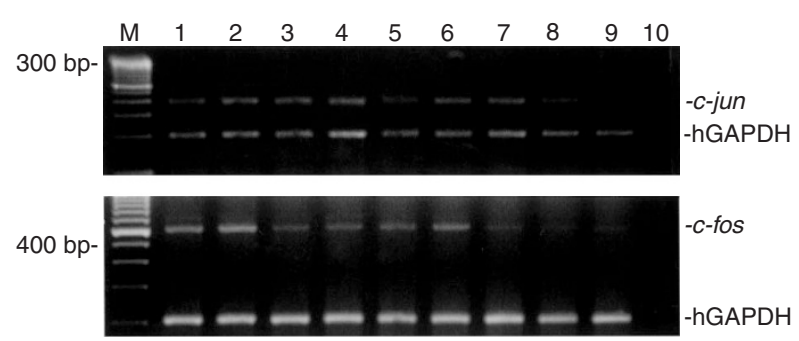

Figure 6 Expression of c-jun and c-fos mRNA in OV-1063 tumours. Total RNA was extracted from tumours and c-jun and hGAPDH as well as c-fos and hGAPDH mRNAs were co-amplified by multiplex RT-PCR and electrophoresed on $2 \%$ agarose. Each RT-PCR reaction was repeated at least three times and similar results were obtained. Lanes 1-3 = expression of c-jun and c-fos mRNA in untreated tumours (control group); lanes 4-6 = expression of $c$-jun and c-fos mRNA in tumours from animals treated with RC-3940-II at a dose of $10 \mu \mathrm{g}$ per day; lanes $7-9=$ expression of c-jun and c-fos mRNA in tumours from animals treated with RC-3940-II at a dose of $20 \mu \mathrm{g}$ per day; $\mathrm{M}=\mathrm{DNA}$ molecular marker

al, 1999). The exposure of OV-1063 cells cultured in vitro to GRP(14-27) resulted in a stimulation of mRNAs for c-jun and cfos oncogenes. The stimulation was maximal at $1 \mathrm{~h}$ for c-jun and at $5 \mathrm{~h}$ for c-fos, while prolonged exposure to GRP(14-27) resulted in a lesser augmentation of the mRNA for these oncogenes. In OV1063 cells cultured in vitro, the stimulation with GRP(14-27) caused a greater induction of mRNA expression for c-jun than for c-fos, in contrast to previous findings in SCLC (Draoui et al, 1995) and malignant glioblastomas (Kiaris et al, 1999). Considering that in all the three tumours GRPR/BRS-1 is the main receptor that mediates the proliferative effects of GRP(14-27), one might postulate that other factors acting downstream of each receptor modify the signal initiated by the ligand-receptor interaction, resulting in specific effects on c-jun or c-fos observed in each cell line. Bombesin/GRP antagonist RC-3940-II blocks the stimulatory action of GRP on c-jun and c-fos mRNAs, while the exposure of OV-1063 cells in vitro to RC-3940-II alone does not affect the mRNA levels of these oncogenes, indicating the absence of any intrinsic GRP activity in this antagonistic analogue of bombesin/GRP. This is in agreement with the finding that mRNA for GRP is not produced by OV-1063 cells and thus, the specific bombesin/GRP antagonist RC-3940-II, when added alone to the culture medium, has no effect in the regulation of c-jun and c-fos oncogenes, and the rate of cell proliferation. The detection of mRNA for the GRP ligand was performed using primers that span the common region of the prepro-GRP to the $3^{\prime}$-untranslated region of the message (Siegfried et al, 1994). Although the detection of the mRNA for GRP by more sensitive methods such as nested PCR and/or Southern blot hybridization cannot be excluded, the autocrine stimulation of this tumour by GRP might be much less important physiologically than paracrine stimulation.

In vivo, the levels of mRNA for c-jun and c-fos oncogenes decreased significantly in tumours of mice receiving RC-3940-II, which is likely due to the blockade of the endogenously produced mouse-derived GRP, since mRNA for GRP could not be detected in OV-1063 cells cultured in vitro. RC-3940-II administered at $20 \mu \mathrm{g}$ per day but not at $10 \mu \mathrm{g}$ per day inhibited significantly the levels of mRNA for c-fos and c-jun oncogenes in vivo. This is interesting because RC-3940-II, at both concentrations, produced significant inhibition of tumour growth. This finding probably indicates that higher levels of RC-3940-II are required for the suppression of c-jun and c-fos mRNA expression, than for inhibition of tumour growth.
The exact mechanism by which GRP stimulates the expression of c-jun and c-fos oncogenes is not completely understood. It has been shown that bombesin/GRP-like peptides stimulate phosphatidylinositol and $\mathrm{Ca}^{2+}$ release (Spindel et al, 1993; Draoui et al, 1995), while the antagonistic analogues of bombesin/GRP downregulate the receptor for epidermal growth factor (Halmos et al, 1997) and inhibit the phosphorylation responses induced by bombesin-like peptides (Liebow et al, 1994). It is possible that the cascade of intracellular events initiated by the binding of bombesin/GRP-like peptides to specific membrane receptors results in the induction of c-jun and c-fos oncogenes. The products of c-jun and c-fos oncogenes form the AP-1 transcription factor, which in turn evokes the expression of genes with AP-1 inducible elements (Halazonetis et al, 1988). The overexpression of the AP-1 transcription factor is a common alteration detected in various cancers. Thus, the association of the anti-tumour activity of bombesin/GRP antagonists with a downregulation of c-jun and c-fos oncogenes and presumably the AP-1 levels would not be unexpected.

In summary, our results indicate that GRP is implicated in the pathogenesis of OV-1063 ovarian epithelial cell carcinoma and its mechanisms of action appears to involve the c-jun and c-fos oncogenes. Antagonistic analogues of bombesin/GRP could be considered for the treatment of ovarian epithelial cancers that depend on the production of bombesin-like peptides.

\section{AKNOWLEDGEMENTS}

We thank Harold Valerio and Anita Feil for technical assistance and Dr H Kiaris for advice in the preparation of the manuscript. The work described in this paper was supported by the Medical Research Service of the Veterans Affairs department (to AVS) and by a grant from ASTA Medica (Frankfurt am Main, Germany) to Tulane University School of Medicine (to AVS).

\section{REFERENCES}

Bajusz S, Csernus VJ, Janaky T, Bokser L, Fekete M and Schally AV (1988) New antagonists of LH-RH: II. Inhibition and potentiation of LH-RH by closely related analogues. Int J Peptide Protein Res 32: 425-435

Bernhardt G, Reile H, Birnbock H, Sprub T and Schonenberger H (1992) Standardized kinetic microassay to quantify differential chemosensitivity on the basis of proliferative activity. J Cancer Res Clin Oncol 118: 35-43

Bologna MC, Festuccia C, Muzi P, Biordi L and Ciomei M (1989) Bombesin stimulates growth of human prostatic cancer cells in vitro. Cancer 63 : 1714-1720

Cai RZ, Reile H, Armatis P and Schally AV (1994) Potent bombesin antagonists with C-terminal Leu $\psi\left(\mathrm{CH}_{2} \mathrm{~N}\right)$ Tac- $\mathrm{NH}_{2}$ or its derivatives. Proc Natl Acad Sci USA 91: 12664-12668

Carney DN, Cuttitta F, Moody TW and Minna JD (1987) Selective stimulation of small cell lung cancer clonal growth by bombesin and gastrin-releasing peptides. Cancer Res 47: 821-825

Chegini N, Rong H, Dou Q, Kipersztok C and Williams ARS (1996) Gonadotropinreleasing hormone $(\mathrm{GnRH})$ and $\mathrm{GnRH}$ receptor gene expression in human myometrium and leiomyomata and the direct action of GNRH analogs on myometrial smooth muscle cells and interaction with ovarian steroids in vitro. $J$ Clin Endocrinol Metab 81: 3215-3221

Cuttitta F, Carney DN, Mulshine J, Moody TW, Fedorko J, Fishler A and Minna JD (1985) Bombesin-like peptides can function as autocrine growth factors in human small-cell lung cancer. Nature 316: 823-826

Draoui M, Chung P, Park M, Birrer M, Jakowlew S and Moody TW (1995) Bombesin stimulates c-fos and c-jun mRNAs in small cell lung cancer cells. Peptides 16: 289-292

Emons G, Muller V, Ortmann O and Schulz K-D (1998) Effects of LH-RHanalogues on mitogenic signal transduction in cancer cells. J Steroid Biochem Mol Biol 65: 199-206 
Halazonetis TD, Georgopoulos K, Greenberg ME and Leder P (1988) C-jun dimerizes with itself and with c-fos, forming complexes of different DNA binding affinities. Cell 55: $917-924$

Halmos G, Wittliff JL and Schally AV (1995) Characterization of bombesin/GRP receptors in human breast cancer and their relationship to steroid receptor expression. Cancer Res 53: 280-287

Halmos G and Schally AV (1997) Reduction in receptors for bombesin and epidermal growth factor in xenografts of human small-cell lung cancer after treatment with bombesin antagonist RC-3095. Proc Natl Acad Sci USA 94: 956-960

Horowitz AT, Treves AJ, Voss R, Okon E, Fuks Z, Davinson L and Biran S (1985) A new human ovarian carcinoma cell line: establishment and analysis of tumour associated markers. Oncology 42: 332-337

Jungwirth A, Galvan G, Pinski J, Halmos G, Szepeshazi K, Cai RZ, Groot K and Schally AV (1997a) Luteinizing hormone-releasing hormone antagonist Cetrorelix (SB-75) and bombesin antagonist RC-3940-II inhibit the growth of androgen-independent PC-3 prostate cancer in nude mice. Prostate 32 164-172

Jungwirth A, Pinski J, Galvan G, Halmos G, Szepeshazi K, Cai RZ, Groot K, Vadillo-Buenfil M and Schally AV (1997b) Inhibition of growth of androgenindependent DU-145 prostate cancer in vivo by luteinising hormone-releasing hormone antagonist Cetrorelix and bombesin antagonists RC-3940-II and RC3950-II. Eur J Cancer 33: 1141-1148

Jungwirth A, Schally AV, Halmos G, Groot K, Szepeshazi K, Pinski J and Armatis P (1998) Inhibition of the growth of Caki-I human renal adenocarcinoma in vivo by luteinizing hormone-releasing hormone antagonist Cetrorelix, somatostatin analog RC-160, and bombesin antagonist RC-3940-II. Cancer 82: 909-917

Kiaris H, Schally AV, Sun B, Armatis P and Groot K (1999) Inhibition of growth of human malignant glioblastoma in nude mice by antagonists of bombesin/gastrin-releasing peptide. Oncogene 18: 7168-7173

Kim HJ, Evers MB, Banker NA, Greeley GH, Hellmich MR, Thompson JC and Townsend CM (1998) Novel expression and regulation of gastrin gene in human ovarian cancer cell line, SW626. Dig Dis Sci 43: 1465-1473

Koppan M, Halmos G, Arencibia JM, Lambarzi N and Schally AV (1998) Bombesin/Gastrin-Releasing Peptide Antagonists RC-3095 and RC-3940-II inhibit tumour growth and decrease the levels and mRNA expression of epidermal growth factor receptors in H-69 small cell lung carcinoma. Cancer 83: 1335-1343

Landis SH, Murray T, Bolden S and Wingo PA (1999) Cancer Statistics, 1999. CA Cancer J Clin 49: 8-31

Levi F, Lucchini F, Negri E, Boyle P and La Vecchia C (1999) Cancer mortality in Europe, 1990-1994, and an overview of trends from 1955-1994. Eur J Cancer 35: $1447-1516$

Liebow C, Crean DH, Lee MT, Kamer AR, Mang TS and Schally AV (1994) Synergistic effects of bombesin and epidermal growth factor on cancers. Proc Natl Acad Sci USA 91: 3804-3808

Markwalder R and Reubi JC (1999) Gastrin-releasing peptide receptors in the human prostate: Relation to neoplastic transformation. Cancer Res 59: 1152-1159

Miyazaki M, Lamharzi N, Schally AV, Halmos G, Szepeshazi K, Groot K and Cai RZ (1998) Inhibition of growth of MDA-MB-231 human breast cancer xenografts in nude mice by bombesin/gastrin-releasing peptide (GRP) antagonists RC-3940-II and RC-3095. Eur J Cancer 34: 710-717

Moody TW and Cuttitta F (1993) Growth factor and peptide receptors in small cell lung cancer. Life Sci 52: 1161-1173

Nagalla SR, Barry BJ, Creswick KC, Eden P, Taylor JT and Spindel ER (1995) Cloning of a receptor for amphibian [Phe13]bombesin distinct from the receptor for gastrin-releasing peptide: Identification of a fourth bombesin receptor subtype (BR4). Proc Natl Acad Sci USA 92: 6205-6209

Qin Y, Ertl T, Cai RZ, Halmos G and Schally AV (1994a) Inhibitory effect of bombesin receptor antagonist RC-3095 on the growth of human pancreatic cancer cells in vivo and in vitro. Cancer Res 54: 1035-1041
Qin Y, Halmos G, Cai RZ, Szoke B, Ertl T and Schally AV (1994b) Bombesin antagonists inhibit in vitro and in vivo growth of human gastric cancer and binding of bombesin to its receptors. J Cancer Res Clin Oncol 120: 519-528

Radulovic S, Cai RZ, Serfoso P, Groot K, Redding TW, Pinski J and Schally AV (1991) Biological effects and receptor binding affinities of new pseudononapeptide bombesin/GRP receptor antagonists with N-terminal D-Trp or D-Tpi. Int J Pept Protein Res 38: 593-600

Reile H, Cai RZ, Armatis P and Schally AV (1995) New antagonists of bombesin/gastrin-releasing peptide with C-terminal Leu $\psi\left(\mathrm{CH}_{2} \mathrm{~N}\right) \mathrm{Tac}-\mathrm{NH}_{2}$. Int J Oncol 7: 749-754

Schally AV and Comaru-Schally AM (1997) Hypothalamic and other peptide hormones. In Cancer Medicine (4th edn), Holland JF, Frei III E, Bast Jr RC, Kufe DE, Morton DL and Weichselbaum RR (eds), pp 1067-1086. Williams and Wilkins: Baltimore

Shirahige Y, Cai RZ, Szepeshazi K, Halmos G, Pinski J, Groot K and Schally AV (1994) Inhibitory effect of bombesin/gastrin-releasing peptide (GRP) antagonists RC-3950-II and RC-3095 on MCF7-MIII human breast cancer xenografts in nude mice. Biomed Pharmacother 48: 465-472

Siegfried JM, Han YH, DeMichele MAA, Hunt JD, Gaither AL and Cuttitta F (1994) Production of gastrin-releasin peptide by a non-small cell lung carcinoma cell line adapted to serum-free and growth factor-free conditions J Biol Chem 269: 8596-8603

Spindel ER, Giladi E, Segerson TP and Nagalla S (1993) Bombesin-like peptides: of ligands and receptors. Recent Prog Horm Res 48: 365-391

Steel RGD and Torrie J (1976) Principles and Procedures of Statistics. McGraw Hill: New York

Sun B, Schally AV and Halmos G (2000) The presence of receptors for bombesin/ GRP and mRNA for three receptor subtypes in human ovarian epithelial cancers. Reg Peptides 90: 77-84

Sun B, Halmos G, Schally AV, Wang X and Martinez M (2000) The presence of receptors for bombesin/gastrin-releasing peptide and mRNA for 3 receptor subtypes in human prostate cancers. Prostate 42: 295-303

Szepeshazi K, Schally AV, Halmos G, Groot K and Radulovic S (1992) Growth inhibition of estrogen-dependent and estrogen-independent MXT mammary cancers in mice by the bombesin and gastrin-releasing peptide antagonist RC3095. J Natl Cancer Inst 84: 1915-1922

Szepeshazi K, Schally AV, Halmos G, Lamharzi N, Groot K and Horvath JE (1997) A single in vivo administration of bombesin antagonist RC-3095 reduces the levels and mRNA expression of epidermal growth factor receptors in MXT mouse mammary cancers. Proc Natl Acad Sci USA 94: 10913-10918

Tomayko MM and Reynolds CP (1989) Determination of subcutaneous tumour size in athymic (nude) mice. Cancer Chemother Pharmacol 24: 148-154

UKCCCR (1998) United Kingdom Coordinating Committee on Cancer Research (UKCCCR) guidelines for the welfare of animals in experimental neoplasia (2nd edn). Br J Cancer 77: 1-10

Wang QJ, Knezetic AJ, Schally AV, Pour PM and Adrian T (1996) Bombesin may stimulate proliferation of human pancreatic cancer cells through an autocrine pathway. Int J Cancer 68: 1-7

Yano T, Pinski J, Groot K and Schally AV (1992) Stimulation by bombesin and inhibition by bombesin/gastrin releasing peptide antagonist RC-3950 of growth of human breast cancer cell lines. Cancer Res 54: 4545-4547

Yano T, Pinski J, Szepeshazi K, Halmos G, Radulovic S, Groot K and Schally AV (1993) Inhibitory effect of bombesin/GRP antagonist RC-3095 and luteinizing hormone-releasing hormone antagonist SB-75 on the growth of MCF-7 MIII human breast cancer xenografts in athymic nude mice. Cancer 73: 1229-1238

Yano T, Pinski J, Halmos G, Szepeshazi K, Groot K and Schally AV (1994) Inhibition of growth of OV-1063 human epithelial ovarian cancer xenografts in nude mice by treatment with luteinizing hormone-releasing hormone antagonist SB-75. Proc Natl Acad Sci USA 91: 7090-7094 